\title{
The Development of Written Language Skills (Reading and Writing) Material Based KKNI Curriculum
}

\author{
Rita Suswati \\ Universitas Negeri Medan, Indonesia \\ rita.suswati@gmail.com
}

\begin{abstract}
The purpose of this research are: (1) to develop the written language skills material based KKNI curriculum; (2) design the appropriate learning materials contented fun and easy task for the students; and (3) to improve students' learning outcomes. The methods used in this research was R\&D which refers to the development model of Borg \& Gall. It was conducted in Medan State University, English Education Program, Class 2016/2017. After product development, the validity of the products was tested by expert media and expert material. Then, the product was tested in one class. Based on the test results, the developing of Written Language Skills (Reading \& Writing Material) materials had influence to increase the cognitive learning outcomes of English Education Students Program. From the result of the research it was found that the students needed more variation of Written Language Skills materials dealing with English language skills (writing and reading) and language components (vocabulary and grammar). Another finding of the research was the students needed materials that were suitable with the KKNI based Curriculum, so what they have learnt in the classroom can be practiced independently. it is also recommended to conduct further research of developing the written language skills materials so it can be used as an alternative for lecturers who teach skills courses in an effort to improve student learning outcomes.
\end{abstract}

Keywords: written language skills material, KKNI

\section{INTRODUCTION}

Reading is one of the skills that the English students should mastered, besides writing, speaking and listening. According to Harmer (2007:) reading is useful for language acquisition. Provided that students more or less understand what they read, the more they read, the better they get at it. Further, Yopp (2001) states that reading can develop students" ability to learn through a text; to expand their ability to think broadly, deeply, and critically about ideas in the text. Using a suitable text for students will motivate them to read and increase their interest in reading.

Based on curriculum of English Education Program at Medan State University, there are stages in learning Reading, starting with Reading 1, Reading 2, Reading 3, and Reading 4. Since 2016, Medan State University applying KKNI curriculum which transformed some of skills materials. Reading and Writing becomes one subject under the title Literal Reading, Written Language Skills (Reading and Writing), Contextual Written Language Skills, Reading 4 and there are some strategies in teaching Written Language Skills.

Learning process starts with the teaching administrations, there are Curriculum, Syllabus, RPS (lesson plan), Teaching Media, Instruments, Materials and Sources. There are many factors that can influence the English language learning achievement. Curriculum, lecturer/teacher and learning materials play important role in teaching and learning English as Foreign Language (EFL). KKNI Curriculum focuses on the independency of the students in doing their 6 tasks (Daily Task, Critical Book Review, Critical Journal Review, Mini Research, Idea Engineering, Project) and guiding the students to start their own writing.

National Qualification Framework Indonesia based curriculum or Kurikulum berbasis Kerangka Kualifikasi Nasional Indonesia (KKNI) will increase the quality of universities' graduates. For example. In KKNI, students are expected to start their own competences in practicing their language skills (reading, writing, speaking and listening). They will be guided to write their own sentences or compose a sentence and speak it. Through times not only their competences will be improved, but also they will get used to make a review of an article and start their own title of thesis. They will start to read a lot of references, consult dictionary, access internet, read a lot of thesis which will shape them to be a better learner. Further, the students in doing all kinds of activities and doing the 6 tasks, they have to be able to work as a team and behave well, they will carry them selves well to the lecturer, colleagues and the people that involved with the tasks. It will formed their characters. KKNI is a framework of working qualification classes which juxtaposes, equalizes, integrates education sector and training and working experience in order to grant working recognition of competences in accordance to the position of employment in different sectors.

By the formulation of KKNI based curriculum, it is expected that there is an equalization of education quality. One of the efforts that can be done is by reconstruct the used method. In addition, 
there must be an evaluation and it"s application. For undergraduate program (level 6) there are four characteristics that should be gained based on KKNI, they are: (1) capable to apply science, technology and arts within her/his expertise and adaptable to various situations faced during solving a problem; (2) mastering in depth general and specific theoretical concept of a certain knowledge and capable to formulate related problem solving procedure; (3) capable to take a strategic decision based on information and data analysis and provides direction in choosing several alternative solutions; and (4) responsible for her/his own job and can be assigned to take responsibility of the attainment of organizations, performances.

\section{Written Language Skills Material \\ II. LITERATURE REVIEW}

English Education Program at Medan State University has many subject for each semester. Written Language skills is a subject that the students should take after they passed Literal Reading. Written Language Skills consists of two kind of skills (Reading \& Writing) which has 3 sks and many competences to be mastered. From the preliminary data, it was found that the text books that students used were full of narration without template (animation, picture, photo, etc). So the students felt bored and exhausted in understanding the content of the text. In order to motivate the students interest in studying reading \& writing, the researcher have tried to design and develop the Written Language Skills material based KKNI curriculum.

Each chapter of the Written Language Skills materials consists of 3 parts. First part is the beginning consist of; introduction, objective, basic competency and indicator. The second part is main consist of; material, exercises (group discussion or individual) and the last part is the ending which is the glossary. It's the example of the beginning of each chapter:

\section{CHAPTER 2 \\ IDENTIFYING TOPICS, MAIN IDEAS, AND SUPPORTING DETAILS}

\subsection{INTRODUCTION}

\subsubsection{OBJECTIVE}

The aim of this subject is to identify topics, main ideas and supporting details. After learning about these topics, the students are expected to be able to identify the topics, find the main ideas and supporting details. Futher, they can organise a good paragraph.

\subsubsection{BASIC COMPETENCY}

After learning about Identifying Topics, Main Ideas and Supporting details, students are expected to have some basic competencies:

1. Identify the topics.

2. Find the main ideas.

3. Find the supporting details.

\subsubsection{INDICATOR}

Students are able to :

1. Determine the topic of an essay.

2. Determine the main idea of each essay.

3. Underline the supporting details of each paragraph. 


\section{Material \\ How to Identify the Topics, Main Idea and Supporting Details}
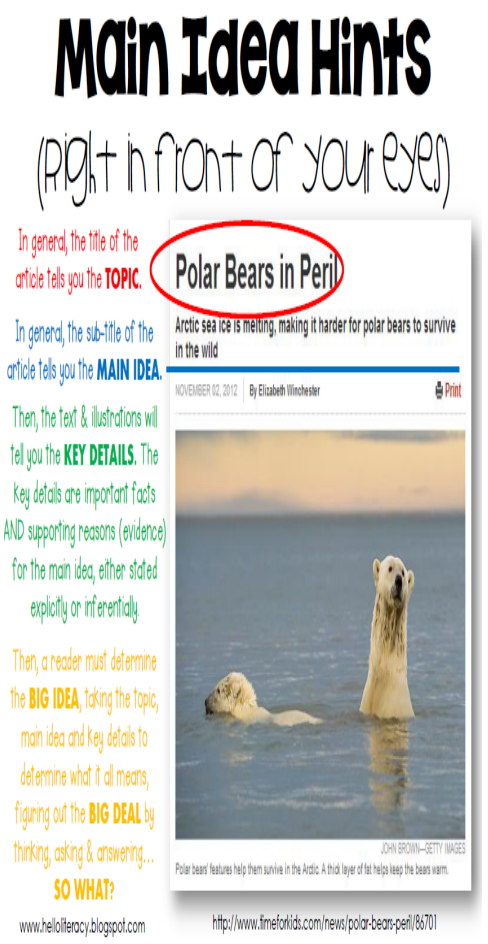

Source: https://i.pinimg.com/originals.png.

\section{Writing a Conclusion}

Write a conclusion which talks about " The Best College Drunk Foods"

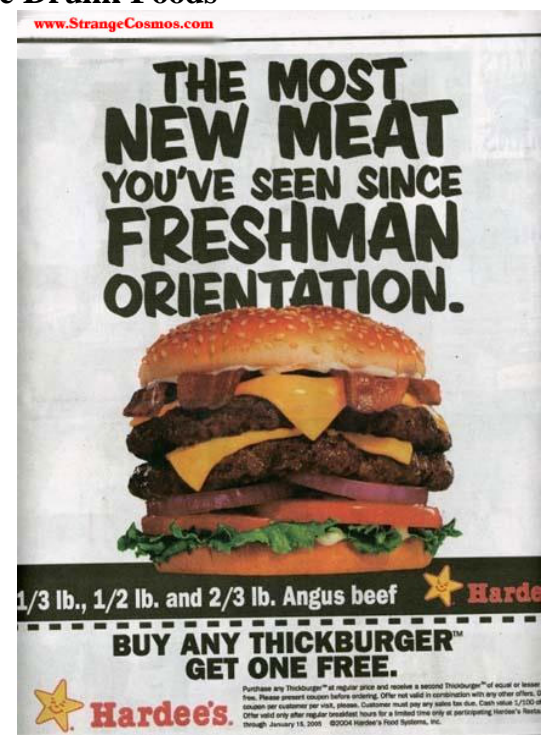

Source: https://www.google.com/search

Restart thesis

Summation

Concluding sentence
The last part is the glossary; consist of new terms that the students found in text.

\section{METHODS}

This research is classified into educational Research and Development (R\&D). According to Borg and Gall (1983) education research and development is a process used to develop and validate educational products. The steps of this process are usually referred to as the $\mathrm{R} \& \mathrm{D}$ cycle, which consists of studying research findings developing the product based on these findings, field testing it in the setting, and revising it to correct the deficiencies found in the field-testing stage. In this research, the research procedures proposed by Borg and Gall (1983) and the model of the materials writing proposed by Jolly and Bolitho in Tomlinson (1998) are combined with some adaptation due to the time efficiency and economical reason.

The research was conducted in Medan State University, English Education Program, Class 2016/2017. The subject of the research was Class D, with the total students of 40 . The research are planned with small random sampling because it will be more feasible and economical. The procedure of the research followed the materials development process proposed by Borg and Gall (1983) which consist of study the research findings related to the product, developing the product, trying out the product in the field, evaluating the effectiveness of the product, and revising the product. The research used the combination of the research procedures proposed by Borg and Gall (1983) and the model of material Written Language Skills proposed by Jolly and Bolitho in Tomlinson (1998). There are five steps used in this research: conducting needs analysis, designing the syllabus, developing the materials (writing the first draft of the materials), expert judgment, and writing the final draft of the materials.

The model of learning materials development in this research was presented as follow: (1) conducting needs Analysis; The researcher conducted needs analysis to collect information which was related to the learner's needs and target needs. It also used to obtain information about students' interest in learning English. The results of the questionnaire were descriptive statistic which describes the students' tendency on components of tasks (goal, input, procedures, teacher's role learners' role, and setting); (2) designing the syllabus, the syllabus was designed based on the core competence and basic competence of junior high school. What should be learn by the learners was determined in this step. The syllabus was made as a representation of the result from needs analysis and as a guideline for developing 
the materials; (3) designing the first draft of the materials, selected materials were be organized and developed based on the syllabus that has been created before. The product was called a draft. There were 9 units of the developed materials which consist of 2 or more tasks in each unit. The materials cover two skills: reading skill and writing skill; (4) expert judgment, it's employed after the first draft has been designed. In this research, the selected lecturer who had competence in judging the materials and experienced in materials development will expert the developed materials. The expert judgment was in the form of questionnaire. The questions included some aspects: content, presentation, language, and graphic; and (5) writing the final draft of the Materials; After the materials are evaluated by the expert, the results of the final data analysis are used to write the final draft of the materials. The final draft was then called as Reading and Writing Materials.

\section{RESULT AND DISCUSSION}

The result of the materials development was an interactive and completed written language skills materials based KKNI curriculum. It's consisted various topics based on RPS and syllabus. The topics were: (1) the essay organization; (2) how to identify the topic, main idea \& supporting details; (3) understanding graphic and visual aids; (4) tones; (5) analytical exposition text; (6) hortatory exposition text; (7) discussion text; (8) news item; and (9) critical judgement.

Based on the students' questionnaire, Written Language Skills materials using various topics and visual aids have improved the creativity and interaction of the students up to $87 \%$ compared to the previous learning materials which was lack of visual aids and full of text.

\section{The Advantages of the Product}

The contents of the book were useful and meaningful because it's based on the students' need and designed based on syllabus and RPS of KKNI. Based on KKNI curriculum, the students should accomplished some competences after learning Written Language Skills. They are: (1) applying the reading comprehension theories about text, essay, and essay organization; (2) identifying main idea's/author's thesis, topic sentence and supporting details; (3) using various kinds of visual aids in reading and writing; (4) distinguishing the authors' styles and purposes in text and newspapers; (5) writing the genre of exposition; (6) writing the genre of report; (7) writing the genre of news item; and (8) making a critical books review. Those competences have been applied in the designing material of Written Language Skills, and fulfilled the students' need.
The result of the contents have been revised by the experts. The revision had a purpose to get the input of adjustment the products with the students' need, KKNI curriculum, various and complete contents of the book, clarity and adequate assessment, the method of teaching. The expects have evaluated the product by supervised the process of designing and developing until the finishing product of the materials. They have given the evaluation, revision, and suggested whether the product can be tested or not. The general result of the experts were the answer "yes or no" in questionnaire based on the indicator of evaluation.

The diction used in the product also required the students' need because each chapter completed with glossary which define all the terms and difficult words found of each chapter. Based on the students observations, questionnaires, interviews and students' sheets, it was found that the students were more interesting and more motivated in studying written language skills or others subjects using the product that has been developed by various template and visual aids.

\section{The Effectiveness of Design}

The materials were designed effectively. Each chapter consisted of 3 important parts. The first part was the beginning; goal of learning, competences and indicators. The second part was the main; material, assessment, (3). Glossary; new terms and difficult words in the text. It's showed that the product have followed the rules in designing a good materials. A good materials should consist of not only the topic which will discussed but also the method that stimulates the students in studying it.

Further, Hutchinson and Waters (1987) stated some points as a guideline in writing the materials: (1) materials provide a stimulus to learning. To encourage the learners to learn, good materials will contain enjoyable activities, opportunities for learners to use their existing knowledge and skills; (2) materials help to organize the teaching learning process by providing an easily understandable knowledge of language to be learnt. Good materials should provide a clear and coherent unit structure which will guide teacher and learner through various activities in such a way as to maximize the chances of learning; (3) materials embody a view of the nature of language and learning. The materials should reflect the writer think about what language learning consists of; (4) materials reflect the nature of learning task. Materials should try to create a balanced outlook which both reflects the complexity of the task, yet makes it appear manageable; (5) materials can have a very useful function in broadening the basis of teacher training, by introducing teachers to 
new technique; and (6) materials provide model of correct and appropriate language use. This is necessary purpose of materials. They are simply providing a good example of language use rather than become a tool for language learning.

\section{The Obstacles that Students Faced in Learning Written Language Skills}

Based on the observation and the data that have been done, the researcher found some obstacles in studying Written Language Skills: (1) the conventional method, which was the lecturer talked all the times, the inappropriate assessment, the design of grouping in the classroom; and (2) the materials which filled with theories have bored the students.

Another problem was the various range of students abilities in understanding language skills have made the difficulty in running the class. Developing and applying materials have helped the students overcame their problems in studying Written Language Skills. Also help the lecturers to accomplish their goal of teaching which is students centered learning (SCL).

\section{Appropriate Technology}

The technology used in finishing the materials were: (1) the product focused on the interactive and completed materials. That has a lot of template (visual aids and picture), and the easiest way to access the assessment of each chapter; and (2) he product has been chosen and designed in stages, through sequences of tests and revisions, but it still needed suggestion and constructive input for the satisfaction of the stakeholders. The product has been revised by the experts and the field result showed the improvement of students interests in studying Written Language Skills to $87 \%$.

\section{CONCLUSION}

The result of The Development Of Written Language Skills (Reading \& Writing) Material Based KKNI Curriculum showed that the students skills in Reading and Writing can be improved by applying the stages in teaching using the right materials and KKNI Curriculum. Based on the result of analysis found that learning by using the right materials , method and curriculum have overcame the students problems; lack of confidence and interaction in the educational program at Medan State University.

The development of materials with a lot of template (visual aids and pictures) helped the students to keep on reading and do more writing. The data showed, it was improved up to $87 \%$. of the students interest inlearning. The using of an effective materials based KKNI curriculum, helped not only the students but also the lecturers who run the SCL
(Students Centered Learning) method and taught the same subjects or another subject in English Educational Program of Medan State University.

\section{REFERENCES}

[1] Buzan, T. 2004. Mind Map untuk Meningkatkan Kreatifitas. Jakarta. PT Gramedia Pustaka Utama.

[2] DePorter, B., \& Hernacki, M. 2010. Quantum Learning, Membiasakan Belajar Nyaman dan Menyenangkan. Jakarta: Mizan Medai Utama.

[3] Harmer, J. 2003. English Language Teaching. Cambridge: Cambridge University.

[4] Hutchinson, T., and Waters, A. 1987. English for Specific Purposes : A Learning Centered Approach. Cambridge: Cambridge University Press.

[5] Jolly, D., and Bolitho, R. 1998. A Framework for Materials Writing . In Tomlinson, B. (Ed.)., Materials Development in Language Teaching. Cambridge: Cambridge University Press.

[6] Noor, K. 2013. The Use of Brainstorming to Improve Students' Writing Skill in Descriptive Text (A Classroom Action Research of the Tenth Grade Students of SMA 2 BAE Kudus in the Academic Year 2012/2013). Thesis. Kudus: University of Muria Kudus.

[7] Puskur. 2009. Pengembangan dan Pendidikan Budaya \& Karakter Bangsa: Pedoman Sekolah. Jakarta: Ministry of Education and Culture.

[8] Sugiyono. 2007. Metode Penilaian Pendidikan (Pendekatan Kuantitatif, Kualitatif dan R/D). Bandung: Alfabeta.

[9] Suswati, R. 2011. Implikasi Penerapan Quantum Learning untuk Meningkatkan Reading Skill Mahasiswa Bahasa Inggris UNIMED. Lemlit UNIMED. 